JOURNAL OF INFORMATION AND KNOWLEDGE MANAGEMENT

2020, DEC., VOL. 11, NO. 4, 48-58: ISSN: 2141-4297 (print) 2360-994X (online)

https://dx.doi.org/10.4314/iijikm.v11i4.5
Information

Impact

To cite this article: Ngozi Perpetual Osuchukwu (2020) Perception of Children's Reading with Literature and Audio Visual Materials in the Public Library. Information Impact: Journal of Information and Knowledge Management, 11:4, 48-58, DOI: https://dx.doi.org/10.4314/iijikm.v11i4.5

To link to this article: https://dx.doi.org/10.4314/iijikm.v11i4.5

\title{
Perception of Children's Reading with Literature and Audio Visual Materials in the Public Library
}

\author{
Ngozi Perpetual Osuchukwu \\ Department of Library and Information Science, Nnamdi Azikiwe University, Awka
}

\begin{abstract}
This study examined the perception of children on reading, the audiovisual materials available for children in the public library, kinds of literature children love most, challenges inhibiting children from coming to the library, the lessons learnt and the implications of the findings. The survey took place in the children's department of the divisional library with twenty two (22) children who are registered members of the library. There were four (4) engagements with children using children's literature and audiovisual materials in reading. The instruments used were reading inventory, literature, focus group discussion (FGD) and observation technique. The study found out that the participants loved reading. While 20 participants loved books with pictures, 2 refuted the idea. The challenges revealed that the library is far from their residence, among others. It was recommended that more advocacies should be done to schools for more attendance to children's reading while more audiovisual materials should be provided for meaningful learning. The implication is that if children are not inspired with new reading facilities, their interest will wane which will affect academic and knowledge. With this, the national development will never be actualized because these children are the progressive population for resilient cities and communities.
\end{abstract}

Keywords Audio visual, Children Literature, Public Library, Reading Resources

CONTACT Ngozi Perpetual Osuchukwu ngostary2k@yahoo.com Department of Library and Information Science, Nnamdi Azikiwe University, Awka, Nigeria

2020 The Author Published with License by Information Impact

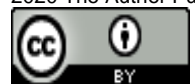




\section{Introduction}

Libraries stock more than just books. There are also audiovisual materials that inspire, engage, enable and connect users to exciting experiences. All these come with aesthetic. It is not a secret that children love colors, colorful artworks and warm ambience. Thus, they come to the libraries to feast their eyes on the non-book resources, knowing that it is a free place and avenue to play with other children and have contacts with adults in reading experiences. This is the right formative stage for children and a period characterized by tremendous drive, character formation and desire to learn (Igwesi, Chimah \& Nwachukwu, 2012). Besides, taking action on children's reading shows care for the future generation and the world we want. Since educationplays critical roles in sustaining national development, libraries and librarians have the responsibilities of creating independent learners, literacy promotion and educational attainment of individuals in every society in the world (Simisaye \&Quadri, 2010) through varieties of needs of the children in the public libraries. The great quote says, "Pictures speak a thousand words." This is true of audiovisual materials, especially in communities' libraries and information centers that have no access to multimedia resources and the sophisticated facilities to render that.

Clearly, audiovisual materials as non-print resources stimulate learning and compels warm platforms for conveying information since they motivate learners to want to learn more and more (Oragui, 2012). The libraries have varieties of non-book resources like colorful art works, promotional posters inspirational quotes (Dewhurst, 2019), charts, pictures, musical instruments, recordings, etc. These audiovisual materials make reading and learning come to life with excitement that is beyond description. It simply goes along with the saying, "tell me I forget, show me I remember, involve me and I understand" (Olaojo \& Gbotoso, 2012). Arguably, acquiring reading culture has something to do with different reading resources. It becomes imperative that for children to learn effectively and pass their class assignments and examinations, they must be exposed with reading right and different methodologies with imageries for sustainable learning.

This makes the public libraries, the best spaces for all members of the society including the children for holistic long life learning. Thus, they become the best bet and safe haven for children (Christopher, 2020) in mixing, mashing and creating excitement all the way.This was echoed by Dewhurst (2019) who stated that students benefit from the solace and protection - the safe space - that the library often provides throughout the day. Indeed, the warmth, peace and the free air in the libraries make them one of the best places to stay in. The reason being that the libraries offer social services laced with psychological and emotional supports. Even with covid-19, librarians device new avenues of providing reading and learning resources for children. Beckingham (2019) aptly stated that Libraries are organic, living entities, constantly changing and adapting to meet their users' needs. Libraries are a Pandora'sbox of knowledge and information. Librarians offer ideas and expertise, and their welcome is warm and sincere.

Essentially, these children need the right literature, reading and learning aids which are good elements of ensuring sustainable cities and communities. Public Library Online (2020) stated anyone that who's worked in a children's room knows that parents don't want to buy the thirty-five books their child wants that day, so coming to the library can be a life (and pocketbook) saver. The fact remains that children read more at the library, they learn more at the library, they trust more in the library and they use more of audiovisual materials in the library. Thus, the study examined the perception of children on reading, the audiovisual materials available for children in the public library, kinds of literature children 
love most, challenges inhibiting children from coming to the library, the lessons learnt and the implications of the findings.

\section{Statement of the problem}

Reading is done in all levels of academic which necessitates that children in the lower classes are supposed to embrace this activity for all time learning. Albeit it to state that the public libraries naturally offer the reading activities to help children build strong knowledge base but their spaces in the libraries are more often than not empty. One may wonder why the children are not coming to enjoy this golden privilege. Observations and experiences show that many children have very poor reading interests. Children need to be inspired more into reading, while some need more than just books to catch their attention since they have different learning interests. Now, if there are enabling environment, good literature and audiovisual materials, children may be attuned to read more and enjoy it. Thus, this study investigated the children's reading preferences with literature and audio visual materials in the public library for better future and national development.

\section{Research question}

The following research questions were formulated for the study:

- What are the perceptions of children on reading?

- What are the literature and audiovisual materials available for children in the public library?

- What kinds of literature do children love most?

- What are the lessons learnt?

- What challenges inhibit children from coming to the library for reading?

- What are the implications of the findings?

\section{Literature review}

Reading is very important in everyone's life, especially children because they need to be educated in order to function effectively. A child who reads willingly and easily is not afraid of academics. Such child has confidence and holds his own anytime, anywhere, anyhow. Again, who reads is assertive and can form good decision about anything. Thus, there is need to make children read, to make them love books and reading without coercion. This is because it promotes critical thinking, widens horizon,improves vocabulary and reading culture as well as academic performances (Ndanwu \& Onwudinjo, 2019. Osuchukwu \& Edewor, 2015).Now, with these beautiful analogies, reading has no disadvantage for children and when coupled with audiovisual materials, well-formed responsible adults, responsible children will be raised for a better society. The fact is that when children are not inspired to read and learn, it may likely affect their abilities to succeed in school and the resultant effect is poor grades. With poor grades come frustration and the desire to drop out which will increase mediocrity, lowering the sustainable development of the nation (Silbert, 2014). Certainly, a child who reads speaks well, thinks right and does well in his academic. Children should be guided right at all times. There are many ways young people can be made to love books and reading.

One of the most resources for children's reading is the literature. These include children's books like picture books, story bookscomic books (Bitz, 2019) which are required reading resources that supports learning and education. The children and many young peoplewho areunder the tutelage of their parents and guardians need quality resources for equitable learning. This is their rights as the Human 
Rights convention on the rights of children in receiving and imparting information and ideas of all kinds emphasized oral, writing or print, art and other media of the children's choices (United Nations, 2019). Hence, they are to be respected, served and given all due social services. This is the reason they are incorporated into the library services with reading resources for holistic molding into responsible and literate adults. The fact remains that when children are not inspired with relevant literature in reading and learning, it may likely affect their abilities to succeed in school and the resultant effect is poor grades. With poor grades come frustration and the desire to drop out which will increase mediocrity, lowering the sustainable development of the nation. (Silbert, 2014) The popular slogan of catching them young makes it utmost necessary that they are made to love reading and learning as Igwesi, Chimah and Nwachukwu (2012) pointed out that at this early stage, children are very active; mentally, emotionally and physically, and they have the desire and a natural curiosity to learn.

Audiovisual materials have been found to help retain information days after an oral and visual presentation. Audiovisual materials are good sources that greatly supports oral and written information as well as images, television,films, CD, DVD, videos, sound recordings (Library and Information Network, 2013, Ashikuzzaman, 2013 and Irvington Public Library, 2012).According to Oragui (2012) audiovisual materials generally make teaching and learning easier and less stressful. It strikes a balance of enriched learning among the participants and the facilitator which enlivens all time reading. Nothing excites the children like drawings and colors with good story line. When the children are engaged with AVM, they stream through rich reading contents for lifelong learning (Igwesi, Chima \& Nwachukwu, 2012). This is the reason the librarians recognize the value of graphic books in engaging young readers to promote literacy, social development and community building (Bitz, 2019). This simply expressed the power of combined sound with visual images (Unegbu, 2015) as good sources for information and learning to children. This analysis states the critical need of inspiring children with AVM for enticing reading and learning experiences.

Clearly, public libraries are always be creative, strategic and innovative and think outside the box in rendering services that appeal to children. The public libraries in Nigeria are taking action with children's reading and literacy activities to keep the vibes for better future of the nation. They engage in wide varieties of readership promotion campaign in schools and communities, imbibing reading culture in children (Oyetunji, 2019, Anambra State Library Board Neswletter, 2018). These libraries provide educational resources that are inclusive as well as create spaces for schools and children (Ugodu, 2016). They also establish good relationships with the children by caring, accommodating and being open minded which motivate the children as well as make them to be more confident, creative and knowledgeable in their learning experiences (Sokari, 2013). Library services are improvised and come out of the blues. The add value, improve knowledge, support education, empower, provide leisure and sustain development of children. This is in tandem with Nwafor-Orizu's (2019) emphasis that the survival and readership of strength of all libraries depend on their level of compliance in this wise. Really, public libraries provide good practices in developing literacy activities for knowledge acquisition and retention in children (El-Shaer \& Gaber, 2014).

But then, many public libraries do need more audiovisual materials and other learning aids that inspire children to read. Some of the children's department in the public libraries is mere reading halls with outdated materials (Ogbuiyi, 2015). Again, experiences and observations have shown that the children's departments of public libraries are not always filled with children. One of the reasons is that it was difficult to involve the families, particularly the parents in ensuring regular reading and attendance to children's reading activities (Ramos \& Vila, 2015). Many parents, especially in the metropolitan city of 
Onitsha are very busy with work and business. Maybe, they lose faith in the authenticity of information from the library, undermining one of the most important pillars of the library's value to society, as Smith (2019) remarked. It can also be attributed to the author's statement, where parents said they are afraid to take their children to the beautiful new Austin Public Library because they are troubled by all the homeless people.Children's reading and learning activities are affected when they do not make use of the spaces created for their literacy development.

\section{Methodology}

This was a survey research design and a qualitative study. It was carried out in the children's department of Onitsha Divisional Library. Twenty two (22) children who are registered members of the library participated in the study from different schools and classes. These were children that attend Saturday children's activities. They comprised of 10 girls and 12 boys. The reading activity took place on Saturdays for four (4) consecutive weeks. The resources used for the activities werepicture/story books, charts and pictures. The instruments used for data collection were reading inventory, focus group discussion (FGD) and observation technique. The children filled the inventory and participated in the discussion. At the end of the reading activities, gifts of books were given to the participants as many children stated that they did not have picture/story books. The findings of the reading activities were analyzed and presented in tables in simple frequencies and percentages.

\section{Findings}

Table 1: Characteristics of children in the reading program

\begin{tabular}{|c|c|c|c|}
\hline $\mathbf{S} / \mathbf{N}$ & Items & Frequency & Percentage \\
\hline 1. & $\begin{array}{l}\text { Age: } \\
\text { Below 6years } \\
7-12\end{array}$ & $\begin{array}{l}8 \\
14\end{array}$ & $\begin{array}{l}36.3 \\
63.7\end{array}$ \\
\hline & Total & 22 & $100 \%$ \\
\hline 2. & $\begin{array}{l}\text { Class: } \\
\text { Nursery } \\
\text { Primary }\end{array}$ & $\begin{array}{l}4 \\
18\end{array}$ & $\begin{array}{l}18.1 \\
91.9\end{array}$ \\
\hline & Total & 22 & $100 \%$ \\
\hline 3. & $\begin{array}{l}\text { Sex: } \\
\text { Female } \\
\text { Male }\end{array}$ & $\begin{array}{l}10 \\
12\end{array}$ & $\begin{array}{l}45.5 \\
54.5\end{array}$ \\
\hline & Total & 22 & $100 \%$ \\
\hline
\end{tabular}

The Table on the characteristics of participants shows that twenty two (22) children participated in the study. While 8 children were below 6years, 14 were between the ages of 7-12. Under class, 4 children were in nursery while 18 were in primary. Again, 10 children were female and 12 were males. This shows that the participants cut across all strata of lower education as well involving boys and girls. 
Table 2: Inventory on perception of children on reading

\begin{tabular}{|l|l|l|l|l|}
\hline & & Yes & No & Undecided \\
$\mathbf{S} / \mathbf{N}$ & Items & & \\
\hline 1. & I love reading with computer & 20 & & \\
\hline 2. & I love reading with charts and pictures & 22 & \\
\hline 3. & I love picture/story books & 22 & & \\
\hline 4. & I love reading with others & 15 & 7 & \\
\hline 5. & I can read on my own & 20 & 2 & \\
\hline 6. & I love it when librarians read with us & 22 & & \\
\hline 7. & I enjoy talking about the lessons learnt & 14 & 6 & \\
\hline 8. & I love reading aloud to others & 15 & 2 & 2 \\
\hline 9. & I enjoy answering questions from story books & 20 & 5 \\
\hline 10. & I prefer reading to watching movies & 8 & 14 & 2 \\
\hline
\end{tabular}

The reading inventory shows that all the participants love reading with charts and pictures, picture/story books and when librarians read with them. It also shows that more than half of the participants love reading with others, reading aloud, talking about lessons learnt and answering questions. However, 8 children prefer reading to watching movies. This shows that children have many interest and method of enjoying reading.

Table 3: Observation checklist of literature and audiovisual materials available in the public library

\begin{tabular}{|l|l|c|c|c|}
\hline $\mathbf{S} / \mathbf{N}$ & Items & Available & Not Available & Accessible \\
\hline 1 & Charts & $\checkmark$ & & $\checkmark$ \\
\hline 2 & Pictures & $\checkmark$ & & $\checkmark$ \\
\hline 3 & Musical instruments & $\checkmark$ & & $\checkmark$ \\
\hline 4 & Projector & $\checkmark$ & $\checkmark$ & $\checkmark$ \\
\hline 5 & Radio & & $\checkmark$ & \\
\hline 6 & TV & & $\checkmark$ & \\
\hline 7 & CD & & & \\
\hline 8 & DVD & $\checkmark$ & & $\checkmark$ \\
\hline 9 & Graphics books & $\checkmark$ & & $\checkmark$ \\
\hline 10 & Posters & $\checkmark$ & & $\checkmark$ \\
\hline 11 & Picture/story books & $\checkmark$ & & $\checkmark$ \\
\hline 12 & Children's references & $\checkmark$ & & \\
\hline 13 & Novels & & & \\
\hline
\end{tabular}

Table 3 shows that the public library has children's literature, charts, pictures, musical instruments, projector, graphics books and posters. They were also available and accessible for learning and reading. However, the radio, TV, CD and DVD were not seen. Hence, some audiovisual materials were seen and were accessible for users.

Table 4: Kinds of literature children love most

\begin{tabular}{|l|l|l|l|}
\hline S/N & Items & Frequency & Percentage \\
\hline 1. & Picture books & 20 & 90.9 \\
\hline 2. & Story books & 22 & 100 \\
\hline 3. & Novels without pictures & 2 & 9 \\
\hline 4. & Graphic books & 18 & 81.8 \\
\hline
\end{tabular}

The results on the kinds of literature children love most shows that they all love story books. More than half of the respondents love picture books and graphic books. Only two participants love novels without pictures. 


\section{Challenges that inhibit children from reading and coming to the library always}

From the discussion, the children revealed the followings:

I cannot come to the library alone except my mummy brings me"

The library is too far from our house

I attend lesson on Saturdays

I cannot come every Saturday because of cleaning and washing

I do not have story book

There is no library in my school

We do not go home with books from our school library

\section{What are the lessons learnt:}

More children will come to the library if advocacy is done in their schools

Schools and teachers have the power to make the children to visit the public libraries

Children warm up to new faces who visit their sessions for reading and learning

The children want the librarians to tell their parents to allow them to visit the library often

The children stated that some of their mates want to come to the library but need adult to speak up for them

\section{Discussion}

This study covering children from different classes, ages and sex (Table 1)makes it inclusive participation for best practices in literacy activities. It shows that every child is important with rights to knowledge and information for equitable quality education (UN, 2019). The indication is that creating spaces for all children to participate in reading activities will drive national development as well raise knowledgeable adults who will transform our societies.

That the inventory on perception ofchildren on reading (Table 2) revealed the love of reading, discussions and reading with others and adults show good sign of strategizing more educational activities. It implies that children who are exposed to libraries and resources establish love for reading. This aptly relates to the study of Nwafor-Orizu (2019) which emphasized that the survival and readership of strength of all libraries depend on their level of compliance in planning activities for children. Again that many children prefer movies to reading indicates the importance of integrating AVM to serve the same purpose, especially the ones that supports education.

The discovery that Onitsha Divisional Library has children's literature, charts, pictures, musical instruments, posters and graphic books (Table 3) which are also accessible indicates its efforts in building the future generation of problem solving individuals. The importance of AVM cannot be over emphasized in children's reading and learning. Hence, it rhymes with other researchers claims that oral presentation is improved with non-book materials (Osayuwa-Odigie \& Eneh (2011), sounds and graphic representations (Bitz, 2019 and Unegbu, 2015). Although, Radio, video and television were not seen the other AVMs are good signs of available resources.

Definitely, children love story/picture books and graphic books (Table 4). It is no surprise as these colorful resources attract attention and make learning more enjoyable. This shows that children's literature must be carefully selected to involve the resources with the color and prints so that as to actualize the objectives of children's program. The discussion on challenges which revealed reasons for children's non-attendance to public libraries reading activities indicates the explanation for the empty 
halls in the children's section. Maybe, some parents are really afraid and not comfortable to bring their children to the libraries (Smith, 2019) because of insecurity. The findings that some children have other things to do on Saturdays and some schools not allowing borrowing of books show the need for the librarians in public libraries to embark on readership program and school visitations to device avenues of making the children read more.

Certainly, it also bothers on the lessons learnt to make plans on engaging parents, teachers and children on the importance of reading and participating in libraries activities for national development. Children love excitement and interesting activities. So when such programs are implemented and awareness created, the parents will allow their children to attend, schools will benefit and have more students who are willing to learn and the society will develop more with critical thinkers.

\section{Implication}

The findings of this study have shown that children need exciting engagements with literature and audiovisual materials that add value. Again, the mere statement that public libraries do not have relevant resources for children has been debunked by this study. What this implies is that the public library in Onitsha has all it takes to render relevant services that support children's reading but needs more awareness and engagement with parents and schools for more participation from children who are the focal points of the programs. Therefore, there must be more efforts in outreach not only to schools but to librarians outside the public libraries and other individuals who can assist in offering reading and learning activities to children. This is to make the program more enticing and to reduce the workloads from the staff of public libraries. The implication is that if new strategies are not added, the children can easily become bored which may keep them away from attending. The findings also disclosed that they love to see new faces. Thus, it makes sense to present the children with different adults who can add varieties and unique reading to children. This will help to sustain the children's program in the public library.

\section{Conclusion}

Children need good practices in reading and learning to create that culture of lifelong literacy. When they are guided at the early stages in their life, they tend to translate it to all their levels of education, making them do well in academic exercises. Thus, this study concludes that:

a) Inclusive participation of children in all classes and ages is important in reading program.

b) Reading activities must be made to be enjoyable with different strategies of engagement to add values

c) Varieties of literature and audiovisual materials must be streamed and integrated in the children's reading program

d) Challenges can be minimized, if the librarians in public libraries engage parents and schools in encouraging the children to attend the reading activities.

\section{Recommendations}

Based on the findings, the following recommendations were made:

1. Reading promotion, campaigns and sensitization must be planned for awareness creation to attract children to the libraries

2. There is need for new children's literature because new resources have appealing effects on children 
3. Updated AVMs should be provided for enriched reading and learning. For instance, more of projector led-reading and musical instruments should be used, maybe, quarterly as many children have different learning methods.

4. There should be collaboration with public libraries and organization or other institutions for reading development and volunteers for children's services

5. The Library Bard, government and agencies can be lobbied for resources for children's program.

6. Gifts should be given to children who attend and participate more in the programs. This have indulging effects and the drive to read more.

\section{References}

Anambra State Library Board. (2018). Anambra State Library Board Newsletter. Maiden Edition, 64

Ashikuzzaman, M. (2013). Definition of audiovisual materials, library and information network. Retrieved on 19/5/2018 from www.lisbdnet.com. Library and Information Science Network (2013), Definition of Audio Visual Materials. Retrieved on $13^{\text {th }}$ August, 2020 from http://www.lisbdnet.com/definition-of-audio-visual-materials/

Beckingham, K. (2019). Libraries as safe havens. Retrieved on $15^{\text {th }}$ September, 2020 from https://ietoday.co.uk/facilities-buildings/libraries-as-safe-havens/

Bitz, M. (2019). Comic books and young people: Evolving roles of literacy and libraries in the digital age. In EbeleAnyaoku, Obiajulu, A. Emejulu\&Oyewusi, F. O. (Eds) Library and information services for children and young people in the digital age. Nnewi: Greeno Publishers, $28-43$

Christopher, R. (2020). Free PDF e-book — Library as Safe Haven: Disaster Planning, Response, And Recovery. Retrieved on $15^{\text {th }}$ September, 2020 from https://www.alastore.ala.org/LibraryAsSafeHavenPDF

Dewhurst, V. (2019). A safe haven: Ideas for your school library. Retrieved on $15^{\text {th }}$ September, 2020 from https://www.sec-ed.co.uk/best-practice/a-safe-haven-ideas-for-yourschool-library/

El-Shaer, A. \&Gaber, H. (2014). Impact of problem-based learning on students' critical thinking, dispositions, knowledge acquisition and retention. Journal of Education and Practice. Vol.5 (14):74-86

Igwesi, U., Chimah, J. N. \&Nwachukwu, V. N. (2012). The use of ICTs and audiovisual resources in developing children's reading habits in Nigeria. Library Philosophy and Practice (e$\begin{array}{lllll}\text { Journal). } & \text { Retrieved } & \text { on } & \text { September } & \text { from }\end{array}$ https://digitalcommons.unl.edu/cgi/viewcontent.cgi?article=2074\&context=libphilprac

Irvington Public Library (2012). Report. Retrieved on ...... from irvingtonpubliclibrary.org/aboutipl.shtml

Library and Information Network (2013). Definition of Audio Visual Materials. Retrieved on $12^{\text {th }}$ August 2020 from http://www.lisbdnet.com/definition-of-audio-visual-materials/ 
Ndanwu, A. I. \&Onwudinjo, O. T. U. (2019). Perceptions on improving the reading performance of primary school students in Nigeria. In EbeleAnyaoku, Obiajulu, A. Emejulu\&Oyewusi, F. O. (Eds) Library and information services for children and young people in the digital age. Nnewi: Greeno Publishers, 174-185

Nwafor-Orizu, E. O. (2019). Transforming the library as social space for interaction and learning. In EbeleAnyaoku, Obiajulu, A. Emejulu\&Oyewusi, F. O. (Eds) Library and information services for children and young people in the digital age. Nnewi: Greeno Publishers, 75- 88

Nikitin C. and Jackson, J. (2009). Libraries that matter. Retrieved $1^{\text {st }}$ August, 2020 from https://www.pps.org/article/librariesthatmatter-2

Ogbuiyi, S. (2015). Types of libraries. In V. E. Unegbu\& C. E. Otuza. Use of library and information resources: Library use education. Lagos: Emaphine Reprographics Ltd, 25-34

Olaojo, P. O. \&Gbotoso, S. A. (2012). Availability and utilization of audio-visual media in social studies at the junior secondary school level in Oyo state. Nigerian Libraries, 45 (1), 28-39

Oragui, E. M. (2020). Challenges lecturers and students encounter in the use of audiovisual resources in University libraries in Anambra State. Masters Thesis in the Department of Library and Information Science, University of Nigeria Nsukka, 104

Osayuwa-Odigie, H. T. \&Eneh, A. C. (2001). Preservation and conservation of non-book materials in the University of Benin and Delta state University Libraries. Nigerian Libraries. Vol $44(1), 1-12$

Osuchukwu, N. P. \&Edewor, N. (2015). Make the children read: Participatory rural approach in school libraries in Umueri, Nigeria. Library Philosophy and Practice (e-journal). Paper 1384. http://digitalcommons.unl.edu/libphilprac/1384

Oyetunji, O. D. (2019). Influence of library and information services ergonomics on performance of National library on Nigeria's librarians for intellectual freedom through readership promotion campaign. Nigerian Libraries: Journal of Nigerian Library Association. Vol. (1), 57-66

Public Library Online (2020). Posts tagged 'achieving excellent customer service.Retrieved on $10^{\text {th }}$ August, 2020 from http://publiclibrariesonline.org/tag/achievingexcellent-customer-service/

Ramos, A. M \& Vila, I. (2015). The role of public libraries in promoting reading within the family. International Federation of Library Associations and Institutions 2015, Vol. 41(4) 364-369

Silbert, L. (2014). Poor reading comprehension. Retrieved on June 11, 2019 from https://tigertuesday.com/poor-reading-comprehension/.

Simisaye, A. O., \&Quadri, M. O. (2010). Developing a reading habit in children: Lagos State Library Board Summer Reading Programme experience. Library Philosophy and Practice, 2010. Retrieved from: http://unllib.unl.edu/LPP/simisaye-quadri.htm. On 13th October, 2011.

Smith, M. (2019). Top ten challenges facing public libraries. Journal Public Library Quarterly Vol. 38 (3), 241-247

Sokari, V. (2013). An assessment of the implementation of universal basic education (UBE) policy on establishment of school libraries in Kano state. Masters Degree Thesis, Unpublished. Bayerouniversity, Kano

Ugodu, H. N. (2016). Classification of libraries in Nigerian society, typology of library materials 
and media. In I. O. Eze (Ed). Book of readings in library and information literacy. Enugu: Oktek Publishers, 9-21

Unegbu, V. E. (2015). Information sources/materials: Audiovisual/nonbook. In V. E. Unegbu\&

C. E. Otuza. Use of library and information resources: Library use education. Lagos: Emaphine Reprographics Ltd, 85-90

United Nations (2019). Convention on the Rights of the Child. Accessed on May 26, 2019

from https:/a/www.ohchr.org/en/professionalinterest/pages/crc.aspx 